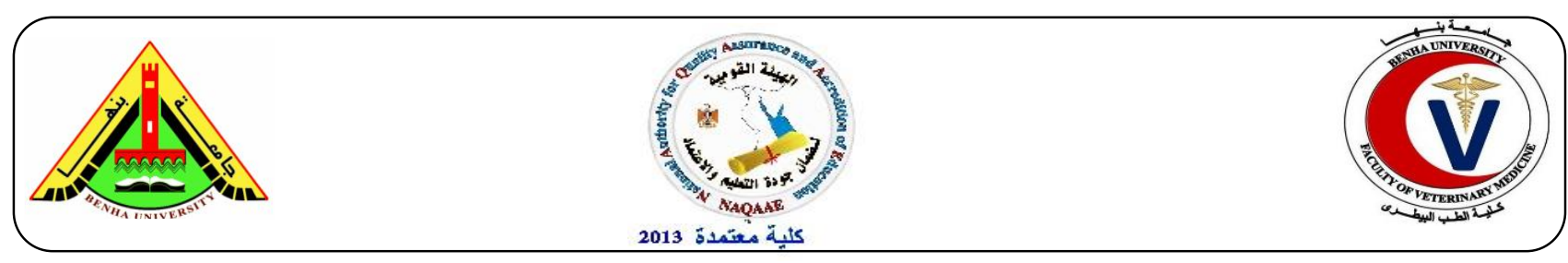

\title{
A Study on The Teratogenic Effect of Spiramycin in Albino Rats.
}

\author{
El-Komy, A.A.A., Abd-El-Baky, Amany E.M. and Abo-el-Ezz, Heba M.A.
}

Department of pharmacology, Faculty of veterinary medicine,Benha University.

\begin{abstract}
A B S T R A C T
Drugs or medicinal agents should only be used in pregnancy if there is proven benefit to the mother and no potential teratogenic risks. The present study was performed to evaluate the teratogenic effect of spiramycin in albino rats. The pregnant rats were divided into three groups, group (1) behaved as control received normal saline from $6^{\text {th }}$ to $15^{\text {h }}$ day of pregnancy. Group (2) received 150 $\mathrm{mg} / \mathrm{kg}$ b.wt of spiramycin orally daily from $6^{\text {th }}$ to $15^{\text {th }}$ day of pregnancy. Group (3) received 300 $\mathrm{mg} / \mathrm{kg}$ b.wt. of spiramycin orally daily from $6^{\text {th }}$ to $15^{\text {th }}$ day of pregnancy There is no death or abortions. Treated groups showed significant decrease in weight, length and retarded growth in fetuses. Fetal resorption significantly increased. The incidences of skeletal and visceral abnormalities were increased in treated groups.
\end{abstract}

Key words: Spiramycin, Pregnancy, Abnormalities.

(http://www.bvmj.bu.edu.eg)

(BVMJ-35(2): 354-363, 2018)

\section{INTRODUCTION}

Macrolide antibiotics are frequently used for Gram-positive lower and upper respiratory infections, Helicobacter pylorirelated peptic ulcer and soft tissue infections. Moreover, for the treatment of chlamydia and other selected infections in pregnancy like Toxoplasma (Lin et al., 2013). Macrolide antibiotics are the second most frequently used antibacterial class during pregnancy (Crider et al., 2009) and (Mitchell et al., 2011).It has excellent in vitro activity which is reported for Gram-positive bacteria and mycoplasma and also for certain Gramnegative microbes such as Actinobacillus pleuropneumoniae, Pasteurella bemolytica, and Pasteurella multocida (Ose and Tonkinson, 1988).
Most therapeutic agents cross placental barrier and enter the circulation of fetus. Every drug given during pregnancy has tendency to produce some sort of structural abnormalities in the neonate (Heikkinen et al., 2000).The most incidence for malformations take place during the period of organogenesis. Drugs given during this period are more likely to induce birth defects. This critical time of fetal developments in rats and mice is from 6 - 12 days of their pregnancy (Somer , 1962).The study of abnormal prenatal development and congenital malformations caused by physical agents or exogenous chemical is a growing area of medical research in the quest for the eradication of preventable birth defects. The aim of this study was to investigate the effect 
of spiramycin administration during gestation on albino rats in term of weight, length, resorption sites and detection of any gross malformations as skeletal and visceral anomalies.

\section{MATERIALS AND METHODS}

2.1. Animals:

The experiment was carried out on albino rats. The age and weight of used rats were 8-10 months and 210-250 gram respectively. Rats were obtained from animal house colony of faculty of Veterinary Medicine, Benha University. Rats were kept under hygienic conditions fed on standard balanced diet and water free from antimicrobials to withdraw any antibacterial residues. Female rats were examined periodically using vaginal smear technique to ensure that they were in regular estrous cycle (Heikkinen et al., 2000). Each female in estrous phase was paired with a male of proven fertility in a separate cage. In the morning, vaginal smear was taken to verify day of pregnancy. Presence of spermatozoa in the obtained vaginal smear suspected pregnancy (Somer, 1962).

\subsection{Drug:}

Spiramycin was manufactured by Arabcomed co., El Obour City, Cairo, Egypt under trade name (SUANO $\left.{ }^{\circledR}\right)$. It is presented in a package of 100 grams spiramycin adipate , corresponding to $150 \mathrm{M} \mathrm{I} \mathrm{U}$ spiramycin base.

\section{RESULTS}

The results indicated that oral administration of spiramycin in $150 \mathrm{mg} / \mathrm{kg}$ b.wt and $300 \mathrm{mg} / \mathrm{kg}$ b.wt from $6^{\text {th }}$ to $15^{\text {th }}$ day of pregnancy to female pregnant rats produced significant increase in number of resorbed fetuses/mother as recorded in table

\subsection{Experimental design:}

The rats were classified into three groups.

Group (1): Ten Pregnant female rats were used as control group and received normal saline according to the method of administration used.

Group (2): Ten pregnant female rats were given $150 \mathrm{mg} / \mathrm{kg} \quad$ b.wt. of spiramycin orally from $6^{\text {th }}$ to $15^{\text {th }}$ day of pregnancy and sacrificed at 20th day of pregnancy to detect teratogenic, histopathological effects of tested drug.

Group (3): Ten pregnant female rats were given $300 \mathrm{mg} / \mathrm{kg}$ b.wt. of spiramycin orally from $6^{\text {th }}$ to $15^{\text {th }}$ day of pregnancy and sacrificed at $20^{\text {th }}$ day of pregnancy to detect teratogenic, histopathological effects of tested drug.

\subsection{Teratological design:}

Pregnant female rats of the three groups were sacrificed at the $20^{\text {th }}$ day of gestation and dissected to examine the effect of the administered drug on fetal development by morphological, visceral and skeletal examinations according to (Hayes , 1986).

\subsection{Statistical analysis:}

The data were calculated as mean \pm SEM and were analyzed by using SPSS program (one way ANOVA). Differences were declared significant at $\mathrm{P}<0.001$.

(1). Highly significant decrease in number of fetuses table (2), fetal body weight and length of fetuses were significantly decreased (Table 3 ).

After oral administration of therapeutic dose of spiramycin $(150 \mathrm{mg} / \mathrm{kg}$ b.wt) to pregnant rats from $6^{\text {th }}$ to $15^{\text {th }}$ day of pregnancy visceral examination (Table 4) 
revealed : diverticulum dilation of the brain in $42.31 \%$ (figure 1), absence or hypoplasia of thymus in $30.77 \%$, pulmonary hypoplasia in $15.38 \%$ (figure 2), cardiac enlargement in $11.54 \%$, hepatomegaly in $23.08 \%$ and kidney hypotrophy with dilation of renal pelvis either unilateral or bilateral in $19.23 \%$ ,while visceral examination of fetuses obtained from dams given Orally double therapeutic dose of spiramycin $(300 \mathrm{mg} / \mathrm{kg}$ b.wt) to pregnant rats from $6^{\text {th }}$ to $15^{\text {th }}$ day of pregnancy (Table 4) resulted in diverticulum dilation of the brain in $54.17 \%$, absence or hypoplasia of thymus in $41.67 \%$ (figure 3 ), pulmonary hypoplasia in $41.67 \%$, cardiac enlargement in $37.50 \%$, hepatomegaly in $33.33 \%$ (figure 4) and kidney hypotrophy with dilation of renal pelvis either unilateral or bilateral in $25.0 \%$.

Table (1): Effect of spiramycin on the number of resorbed fetuses obtained from rats administered 150 and $300 \mathrm{mg} / \mathrm{kg}$ b.wt. of spiramycin orally daily from $6^{\text {th }}$ to $15^{\text {th }}$ day of pregnancy $\mathrm{n}=10$

\begin{tabular}{ll} 
Animal group & Number of resorbed fetuses \\
& $\bar{X} \pm \mathrm{S} . \mathrm{E}$ \\
Group (1) control & $0.00 \pm 0.00$ \\
Group (2) & $0.30 \pm 0.21$ \\
Group (3) & $0.60 \pm 0.42$ \\
\hline & $\mathrm{P}<0.001$
\end{tabular}

Table (2): Effect of spiramycin on the number of viable and dead fetuses obtained from rats administered 150 and $300 \mathrm{mg} / \mathrm{kg}$ b.wt of spiramycin orally daily from $6^{\text {th }}$ to $15^{\text {th }}$ day of pregnancy. $(n=10)$

\begin{tabular}{cccc}
\hline & $\begin{array}{c}\text { Number of fetus } \\
\text { Animal group }\end{array}$ & $\begin{array}{c}\text { Number of viable } \\
\text { fetuses }\end{array}$ & $\begin{array}{c}\text { Number of dead } \\
\text { fetuses }\end{array}$ \\
& & $\bar{X} \pm$ S.E & $\bar{X} \pm$ S.E \\
Control & $10.0 \pm 0.394$ & $10.0 \pm 0.394$ & - \\
Group (2) & $6.80 \pm 0.416$ & $6.80 \pm 0.416$ & - \\
Group (3) & $3.40 \pm 0.37$ & $3.40 \pm 0.37$ & - \\
\hline
\end{tabular}


Table (3): Effect of spiramycin on body weight and length of fetus obtained from rats administered 150 and $300 \mathrm{mg} / \mathrm{kg}$ b.wt of spiramycin orally daily from $6^{\text {th }}$ to $15^{\text {th }}$ day of pregnancy. $\mathrm{n}=10$

\begin{tabular}{lll} 
Animal group & $\begin{array}{l}\text { Fetal body length } \\
(\mathrm{cm})\end{array}$ & $\begin{array}{l}\text { Fetal body weight } \\
(\mathrm{gm})\end{array}$ \\
Group(1) Control & $4.513 \pm 0.09$ & $4.226 \pm 0.09$ \\
Group (2) & $3.348 \pm 0.09 * * *$ & $3.427 \pm 0.07 * * *$ \\
Group (3) & $2.568 \pm 0.10 * * *$ & $2.625 \pm 0.10 * * *$ \\
\hline
\end{tabular}

Table (4):Visceral abnormalities in fetuses obtained from rats administered spiramycin (150 mg and $300 \mathrm{mg} / \mathrm{kg}$ b.wt orally, once daily from $6^{\text {th }}$ to $15^{\text {th }}$ day of pregnancy.

\begin{tabular}{lll} 
Abnormalities in & \multicolumn{2}{c}{ Spiramycin } \\
& $(150 \mathrm{mg} / \mathrm{kg} \mathrm{b} . w \mathrm{t})$ & $(300 \mathrm{mg} / \mathrm{kg} \mathrm{b} . \mathrm{wt})$ \\
& $(\mathrm{n}=26)$ & $(\mathrm{n}=24)$ \\
Brain & $42.31 \%$ & $54.17 \%$ \\
Thymus & $30.77 \%$ & $41.67 \%$ \\
Heart & $11.54 \%$ & $37.50 \%$ \\
Lungs & $15.38 \%$ & $41.67 \%$ \\
Liver & $23.08 \%$ & $33.33 \%$ \\
Kidney & $19.23 \%$ & $25.0 \%$ \\
\hline
\end{tabular}

Table(5): Skeletal abnormalities in fetuses obtained from rats administered spiramycin (150 mgand $300 \mathrm{mg} / \mathrm{kg}$ b.wt orally, once daily from $6^{\text {th }}$ to $15^{\text {th }}$ day of pregnancy.

Abnormalities in

Skull

Sternbrea

Ribs

Digital bone

Metatarsal bone

Metacarpal bone

Caudal vertebrae

\section{Spiramycin}

$\begin{array}{ll}(150 \mathrm{mg} / \mathrm{kg} \text { b.wt }) & (300 \mathrm{mg} / \mathrm{kg} \text { b.wt }) \\ (\mathrm{n}=22) & (\mathrm{n}=26)\end{array}$

$59.1 \%$

$61.5 \%$

$50.0 \%$

$53.8 \%$

$40.9 \%$

$50 \%$

$45.5 \%$

$46.2 \%$

$40.9 \%$

$53.8 \%$

$22.7 \%$ $38.09 \%$ 

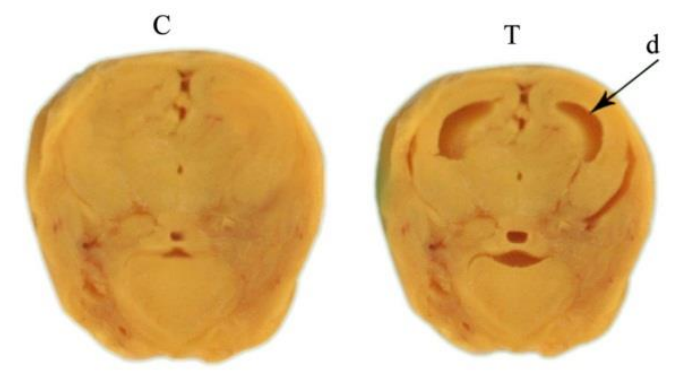

Figure (1):Diverticulum dilitation (d) of brain in a fetus obtained from rat administered therapeutic dose of spiramycin $\left(150 \mathrm{mg} / \mathrm{kg} / \mathrm{b}\right.$.wt.) orally once daily from $6^{\text {th }}$ to $15^{\text {th }}$ day of gestation.

C: Control Fetus

T: Tested Fetus

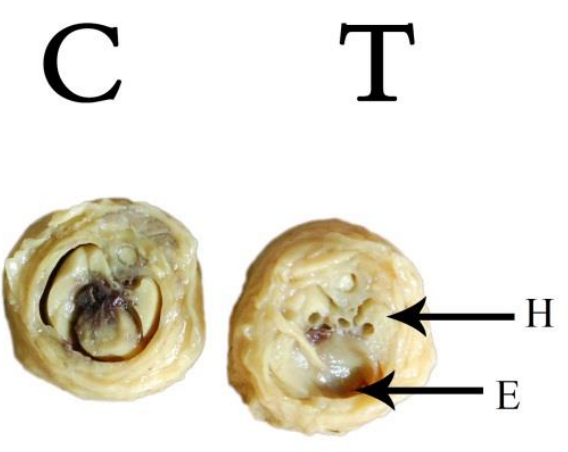

Figure(2):Pulmonary Hypoplasia (H) and cardiac enlargement (E) in a fetus obtained from rat administered therapeutic dose of spiramycin $\left(150 \mathrm{mg} / \mathrm{kg} / \mathrm{b}\right.$.wt.) orally once daily from $6^{\text {th }}$ to $15^{\mathrm{h}}$ day of gestation.

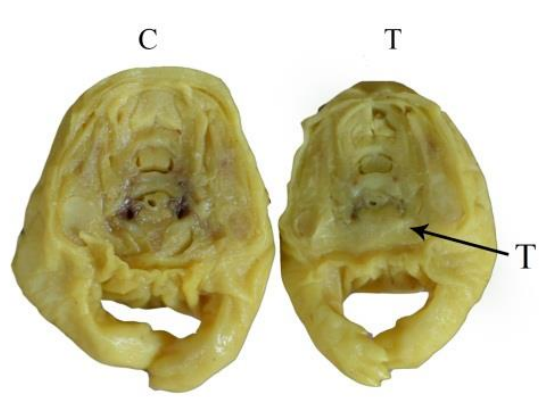

C: Control Fetus

T: Tested Fetus

Figure (3): Thymus Hypoplasia (T) in a fetus obtained from rat administered therapeutic dose of spiramycin $\left(300 \mathrm{mg} / \mathrm{kg} / \mathrm{b} . \mathrm{wt}\right.$.) orally once daily from $6^{\text {th }}$ to $15^{\text {th }}$ day of gestation.
C: Control Fetus
T: Tested Fetus 

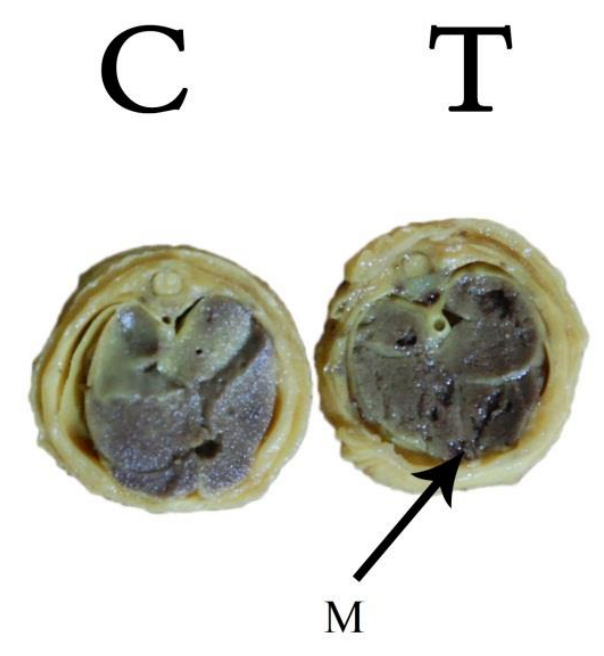

Figure (4)Hepatomegaly (M) in a fetus obtained from rat administered therapeutic dose of spiramycin $\left(300 \mathrm{mg} / \mathrm{kg} / \mathrm{b}\right.$.wt.) orally once daily from $6^{\text {th }}$ to $15^{\text {th }}$ day of gestation.
C: Control Fetus
T: Tested Fetus
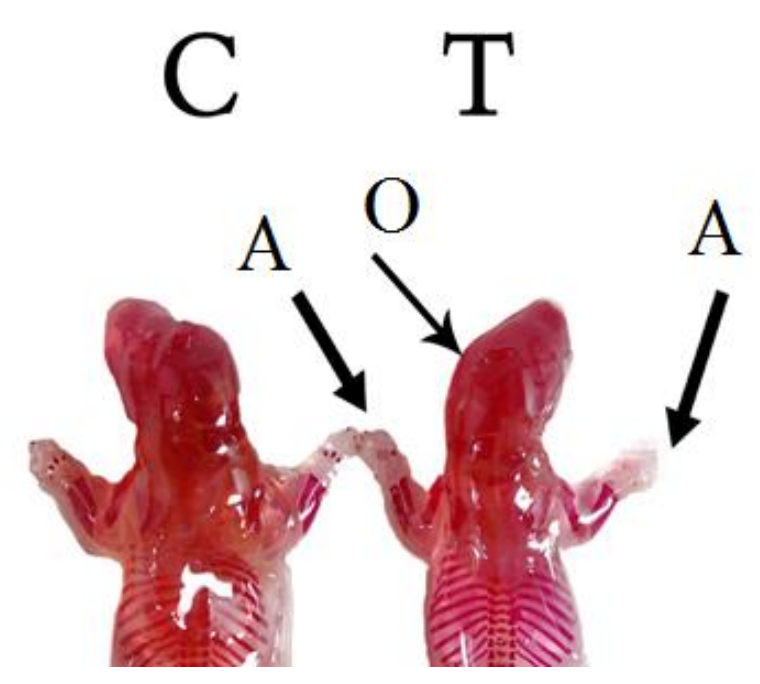

Figure (5): Incomplete ossification (O) of the skull and absence of digital bones (A) of fetus obtained from rat administered spiramycin $\left(150 \mathrm{mg} / \mathrm{b}\right.$.wt) orally, once daily from $6^{\text {th }}$ to $15^{\text {th }}$ day of gestation $(n=10)$.

C: Control fetus $\quad$ T: Treated fetus 

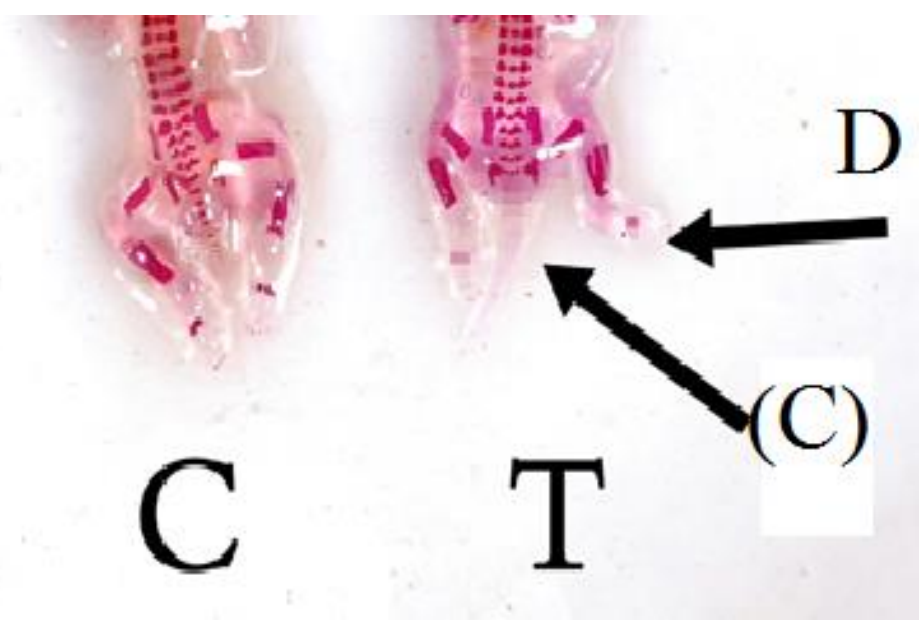

Figure (6): Complete absence of caudal vertebrae (C) and absence of some digital bones (D) in a fetus obtained from rat administered spiramycin daily orally (150 mg/kg b.wt.) from $6^{\text {th }}$ to $15^{\text {th }}$ day of gestation.

C: Control fetus

T: Treated fetus

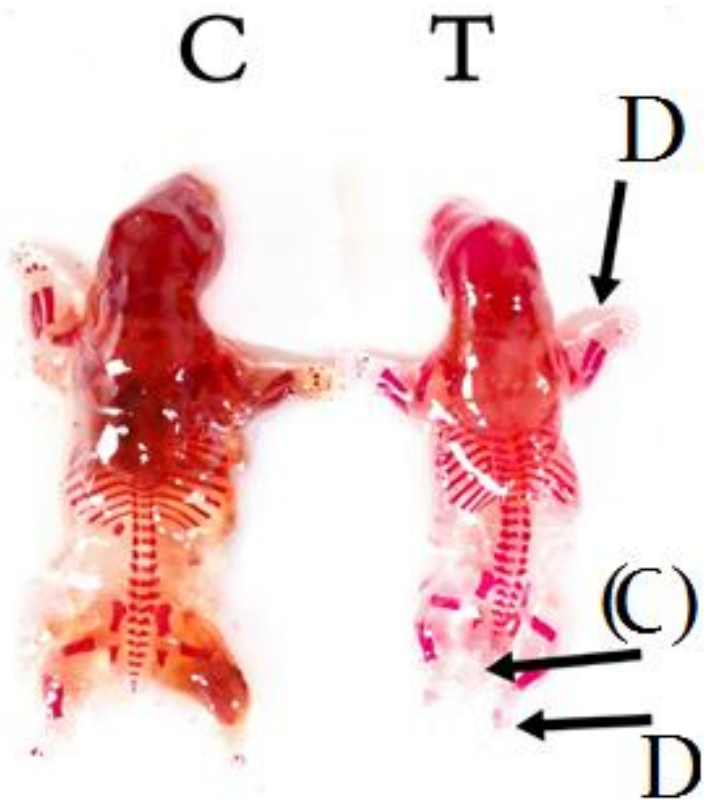

Figure (7): Complete absence of caudal vertebrae (C) and digital bones (D) in a fetus obtained from rat administered spiramycin daily orally ( $300 \mathrm{mg} / \mathrm{kg}$ b.wt.) from $6^{\text {th }}$ to $15^{\text {th }}$ day of gestation.

$\mathrm{C}$ : Control fetus

T: Treated fetus

\section{DISCUSSION}

Oral administration of spiramycin by using stomach tube in therapeutic and double therapeutic doses (150 and $300 \mathrm{mg} / \mathrm{kg}$ b.wt) to female pregnant rats induced marked and significant decrease in the number of feti/mother when compared with that of the control group without any fetal deaths. The decrease in the number of feti/mother might be attributed to the direct toxic action of the tested drug on the early developed fertilized 
ovum or the lack of oval production or of the basic cell constituent by the mother (Tuchmann-Duplessis, 1975). Spiramycin in therapeutic and double therapeutic doses resulted in marked increase in the number of resorbed feti either early or late. This result was similar to that reported by (El-Sayed et al., 2014) The increase in the number of resorbed fetuses in the present study might be attributed to the interference of the tested drug with the placental transmission of leucin amino acid and magnesium as deficiency of leucin or magnesium produced high incidence of fetal resorptions (Tuchmann- Duplessis, 1975). Administration of spiramycin in therapeutic and double therapeutic dose to female pregnant rats during the period of organogenesis produced significant decrease in both weight and length of fetuses. This result was consistent with that reported by (Karabulut et al., 2008). There was significant decrease in all growth and developmental parameters following administration of macrolides in cultured rat embryos dose dependently. The recorded reduction in fetal weight and length which resulted after oral administration of tested drug might be attributed to the disturbance in metabolism of some minerals as magnesium and zinc in fetus, or to the interference of the drug to the placental transmission of magnesium and zinc from the mother to the fetus (TuchmannDuplessis , 1975)as deficiencies of magnesium and zinc induced retardation of fetal growth, increasing fetal resorption and high rate of embryonic death.

Administration of therapeutic and double therapeutic doses of spiramycin to female pregnant rats during the period of organogenesis caused many fetal visceral abnormalities as diverticulum dilatation in the brain of fetuses. The obtained result was consistent with those reported by (Karabulut et al., 2008). Also another study (Moriyama et al., 2011) concluded that treatment with rapamycin induced enormous influences on early developmental period. This lesion might be attributed to the transfusion of arginine amino acid caused by this drug or to the disturbance of the metabolism of arginine in fetus (Tuchmann-Duplessis, 1975) proved that, deficiency of arginine in pregnant rat or mice resulted in brain abnormalities such as diverticulum dilatation due to inhibition of cell differentiation. Spiramycin in the therapeutic and double therapeutic dose resulted in hypoplasia of thymus gland, which was a dose-dependent. This result was similar to that reported by (Jordan and Higdon , 1988).Administration of tilmicosin to rats induced both total visceral and skeletal anomalies and with (Petrova and Savitskaia , 1988) following administration of oleandomycin in rats.(Takai et al., 1990) recorded that; tacrolimus might impair thymic microenvironment and disturb the thymocyte maturation. Other investigators as (Moriyama et al., 2011), mentioned that rapamycin induced enormous influences on early developmental period. Administration of spiramycin in therapeutic and double therapeutic dose to female pregnant rats produced cardiac hyperplasia which was a dose-dependent. These fetal abnormalities similar to that reported by (Jordan and Bernard, 1989) following administration of tilmicosin to female rats and by (Otterblad and Danielsson , 2005) reported that erythromycin induced congenital malformation.

Administration of spiramycin in therapeutic and double therapeutic dose to female pregnant rats from $6^{\text {th }}$ to $15^{\text {th }}$ day of pregnancy induced pulmonary hypoplasia which was dose -dependent. Similar results were obtained by (Karabulut et al., 2008). reported that, there was significant decrease in all growth and developmental parameters following administration of macrolides in cultured rat embryos dose dependently. 
Administration of spiramycin produced hepatomegaly. This result agrees with (Jordan and Higdon , 1988).administration of tilmicosin to rats induced both total visceral and skeletal anomalies. Administration of spiramycin in therapeutic and double therapeutic dose to female pregnant rats induced hypoplasia of one or both kidneys with unilateral or bilateral dilatation of renal pelvis. This result was dose- dependent. The same result was recorded by (Nielson et al., 1995) following administration of tacrolimus to pregnant rats. Administration of spiramycin in therapeutic and double therapeutic dose produced some fetal skeletal malformations such as impaired ossification of skull, absence of sternbrae, reduction or absence of caudal vertebrae, absence of digit's bone of fore and hind limb and absence of some metacarpal and metatarsal bone. This result agree with that reported by many investigators as (Phornphutkul et al., 2009)and (Noda, 1993).The reported bone lesion might be attributed to deficiency of functionally available magnesium . (Menschik et al., 1997).

\section{CONCLUSION}

Administration of spiramycin during period of organogenesis especially at high dose induced some fetal defects and abnormalities, so it is advisable to avoid using during pregnancy.

\section{REFERENCES}

Crider,K.S.; Cleves,M.A.; Reefhuis,J.; Berry,R.J.; Hobbs,C.A.and Hu,D.J.(2009): Antibacterial Medication Use during Pregnancy and Risk of Birth Defects: National Birth Defects Prevention Study.Archives of Pediatrics and Adolescent Medicine, 163, 978-985. http://dx.doi.org/10.1001/archpe diatrics.2009.188

El-sayed, M.G.A.; El- Komy, A.A.A.and Abd-El-Baky, Amany A.A.(2014): Evaluation of Teratogenic Potentials and Tissue Residues of Tiamulin in Albino Rats.Nature and Science, 12, 100-105.

Hayes, A.W. (1986): Principles and methods of toxicology. Raven Press. New York. 11.

Heikkinen, K.; Laine, P.J.; Neuvonen, U. and Ekblad. (2000): The transplacental transfer of the macrolide antibiotics erythromycin, roxithromycin and azithromycin. BJOG an international journal of obstetrics and gynaecology 2000; $\quad 107,6,770$ -

775.http://dx.doi.org/10.1111/j. 1471-0528.2000.tb13339.x

Jordan, W.H and Higdon, G.L.(1988): A teratological study of tilmicosin adminstered orally to rats. Submitted to WHO .

Jordan, W.H. and Bernard, N.R. (1989): Chronic toxicity study in beagle dogs given oral doses of tilmicosin. Upublished study No. Do7187 from Lilly Research Laboratories. Submitted from Lilly, Basingstoke, UK.

Karabulut, A.K.; Uysal, I. I.; Acar, H. and Fazliogullari.

$\mathrm{Z}$.

(2008):

Investigation of Developmental Toxicity and Teratogenicity of Macrolide Antibiotics in Cultured Rat Embryos. Histologia, Embryologia; 37, 5, 369-375.

Lin,K.J. ; Mitchell,A.A.; Yau,W.P.; Louik,C. and Hernández-Díaz,S. (2013): Safety of Macrolides during Pregnancy. American Journal of 
Obstetrics

and

Gynecology,208,221228.

http://dx.doi.org/10.1016/j.ajog.2012 .12 .023

Menschik, M.; Neumuller, J.; Steiner, C.W.; Erlacher, L,; Koller, M.; Ullrich, R.; Graninger, W. and Graninger, W.B. (1997): Effect of ciprofloxacin and ofloxacin in adult human cartilage in vitro.. Antimicrob. Agents Chemother., 41, 2562-2565.

Mitchell,A.A.; Gilboa,S.M.; Werler, M.M.; Kelley,K.E.; Louik,C. and Hernandez,S.D.(2011):Medication

Use during Pregnancy, with Particular Focus on Prescription Drugs: 1976-2008.American Journal of Obstetrics and Gynecology, 205, 51-58.

http://dx.doi.org/10.1016/j.ajog.2011 .02 .029

Moriyama,Y.;Ohata,Y.;Mori,S.;Matsukawa,S. ;Michiue,T.;Asashima,M.and

Kuroda,H. (2011): Rapamycin Treatment Causes Developmental Delay, Pigmentation Defects, and Gastrointestinal Malformation on Xenopus Embryogenesis.

Biochemical and Biophysical Research Communications,404,974978.

http://dx.doi.org/10.1016/j.bbrc.2010 .12 .093

Nielson, F.T.; Leyssac, P.P.; Kemp, E.; Starklint, H. and Dieperink, H.(1995): Studies on glomerular and tubular function, and on the relationship between efficacy and toxicity. Nephrotoxicity of FK-506 in the rat. Nephrol Dial Transplant.;10(3):334-40.

Noda, A. (1993): Teratogenicity study of EL870 (tilmicosin aqueous) in rabbits by gavage. Unpublished study No.
91-001 from Research Institute for Animal Science in Biochemistry andToxicology, Japan. Submitted to WHO by Lilly, Basingstoke, UK.

Ose,E.E. and Tonkinson,L.V.(1988): SingleDose Treatment of Neonatal Calf Pneumonia With theNew Macrolide Antibiotic Tilmicosin.VeterinaryRecord,123,36 7369.http://dx.doi.org/10.1136/vr.123.14.367

Otterblad, O. P. and Danielsson, B.R.(2005): Is erythromycin therapy teratogenic in human therapy Reprod Toxicol. Jul-Aug; 20(2):209-14.

Petrova,P. and Savitskaia,T.N.(1988): Prenatal Effect of Oleandomycin on the Development of the Immunogenesis Organs. Farmakologiia and Toksikologiia, 51,85-86.

Phornphutkul, C.; Lee, M.; Voigt, C.; Wu, K.Y.; Ehrlich, M.G.; Gruppuso, P.A. and Chen, Q.(2009): The effect of rapamycin on bone growth in rabbits. J Orthop Res. 2009 Sep;27(9):115761.

Somer, G.F. (1962) Thalidomide and congenital abnormalities. Lancet., vol. 1, p. 912-913.

Takai,K.; Jojima,K.; Sakatoku,J. and Fukumoto,T. (1990): Effects of FK506 on Rat Thymus: Time-Course Analysis by Immunoperoxidase Technique and Flow Cytofluorometry . Clinical and Experimental Immunology, 82, 445449.

http://dx.doi.org/10.1111/j.13652249.1990.tb05469.x

Tuchmann-Duplessis, (1975): Drug effect on the fetus. ADIS press, New York, USA. 